\title{
Cost Effectiveness of Combined Spa-Exercise Therapy in Ankylosing Spondylitis: A Randomized Controlled Trial
}

\author{
ASTRID VAN TUBERGEN, ${ }^{1}$ ANNELIES BOONEN, ${ }^{1}$ ROBERT LANDEWÉ, ${ }^{2}$ \\ MAUREEN RUTTEN-VAN MÖLKEN, ${ }^{3}$ DÉSIRÉE VAN DER HEIJDE, ${ }^{4}$ ALITA HIDDING, ${ }^{5}$ AND \\ SJEF VAN DER LINDEN ${ }^{1}$
}

Objective. To evaluate the cost effectiveness and cost utility of a 3-week course of combined spa therapy and exercise therapy in addition to standard treatment consisting of antiinflammatory drugs and weekly group physical therapy in ankylosing spondylitis (AS) patients.

Methods. A total of 120 Dutch outpatients with AS were randomly allocated into 3 groups of 40 patients each. Group 1 was treated in a spa resort in Bad Hofgastein, Austria; group 2 in a spa resort in Arcen, The Netherlands. The control group stayed at home and continued their usual activities and standard treatment during the intervention weeks. After the intervention, all patients followed weekly group physical therapy. The total study period was 40 weeks. Effectiveness of the intervention was assessed by functional ability using the Bath Ankylosing Spondylitis Function Index (BASFI). Utilities were measured with the EuroQoL (EQ-5D $\mathrm{D}_{\text {utility }}$ ). A time-integrated summary score defined the clinical effects (BASFI-area under the curve [AUC]) and utilities (EQ-5D utility AUC) over time. Both direct (health care and non-health care) and indirect costs were included. Resource utilization and absence from work were registered weekly by the patients in a diary. All costs were calculated from a societal perspective.

Results. A total of 111 patients completed the diary. The between-group difference for the BASFI-AUC was $1.0(95 \%$ confidence interval $[95 \% \mathrm{CI}] \mathrm{0.4-1.6} ; \boldsymbol{P}=\mathbf{0 . 0 0 1}$ ) for group 1 versus controls, and $0.6(95 \% \mathrm{CI} 0.1-1.1 ; P=0.020)$ for group 2 versus controls. The between-group difference for $\mathrm{EQ}-5 \mathrm{D}_{\mathrm{utility}}-\mathrm{AUC}$ was $0.17(95 \% \mathrm{CI} 0.09-0.25 ; P<0.001)$ for group 1 versus controls, and $0.08(95 \% \mathrm{CI} 0.00-0.15 ; P=0.04)$ for group 2 versus controls. The mean total costs per patient (including costs for spa therapy) in Euros (€) during the study period were €3,023 for group 1, €3,240 for group 2, and €1,754 for the control group. The incremental cost-effectiveness ratio per unit effect gained in functional ability (0-10 scale) was $€ 1,269$ (95\% CI $497-3,316)$ for group 1 , and $€ 2,477(95 \%$ CI 601-12,098) for group 2 . The costs per quality-adjusted life year gained were $€ 7,465$ $(95 \%$ CI 3,294-14,686) for group 1, and $€ 18,575$ (95\% CI 3,678-114,257) for group 2.

Conclusion. Combined spa-exercise therapy besides standard treatment with drugs and weekly group physical therapy is more effective and shows favorable cost-effectiveness and cost-utility ratios compared with standard treatment alone in patients with AS.

KEY WORDS. Cost-effectiveness analysis; Cost-utility analysis; Randomized clinical trial; Ankylosing spondylitis; Spa therapy.

\section{INTRODUCTION}

Treatment of ankylosing spondylitis (AS) is aimed at reducing symptoms and preventing, or at least minimizing, spinal deformity and disability. Standard treatment of ac-

${ }^{1}$ Astrid van Tubergen, MD, Annelies Boonen, MD, Sjef van der Linden, MD, PhD: University Hospital Maastricht, Maastricht, The Netherlands; ${ }^{2}$ Robert Landewé, MD, PhD: University Hospital Maastricht, Maastricht, and Atrium Medical Center, Heerlen, The Netherlands; ${ }^{3}$ Maureen Rutten-van Mölken, PhD: Erasmus University Rotterdam, Rotterdam, The Netherlands; ${ }^{4}$ Désirée van der Heijde, MD, PhD: University Hospital Maastricht, Maastricht, The Netherlands and University Center Diepenbeek, Diepenbeek, Bel- tive AS consists of nonsteroidal antiinflammatory drugs (NSAIDs), which reduce pain and stiffness, and physical therapy, which prevents deformity and improves or maintains mobility, fitness, and strength (1). Patients are advised to exercise daily and to follow weekly group physi-

gium; ${ }^{5}$ Alita Hidding, PT, MSc, PhD: Institute for Rehabilitation Research, Hoensbroek, The Netherlands.

Address correspondence to Astrid van Tubergen, MD, Department of Internal Medicine, Division of Rheumatology, University Hospital Maastricht, Post Office Box 5800, 6202 AZ Maastricht, The Netherlands. E-mail: avantubergen@yahoo.com. Submitted for publication May 9, 2001; accepted in revised form January 19, 2002. 
cal therapy. In addition, patients may annually take courses of spa therapy in a spa resort. Spa therapy has a longstanding history, but apart from the opinions of participants, its value is largely unknown. It is usually considered expensive, and reimbursement by insurance companies is inconsistent.

Recently in a randomized controlled trial in patients with AS, we have demonstrated considerable and persistent improvements in a variety of clinical outcomes after a 3-week course of spa therapy in combination with physical exercises in addition to standard treatment with NSAIDs and weekly group physical therapy compared with standard treatment alone (2). In this article we present the results of incremental cost-effectiveness and cost-utility analyses of combined spa therapy and exercise therapy in patients with AS.

\section{PATIENTS AND METHODS}

Design. This economic evaluation, performed from a societal perspective, was designed alongside a randomized, controlled trial on the efficacy of combined spaexercise therapy in AS. The methodology of this trial has been published elsewhere (2). In brief, 120 Dutch patients with active AS were recruited and randomly allocated to 3 groups of 40 patients each. Group 1 received spa therapy at a spa resort in Bad Hofgastein, Austria. Group 2 received spa therapy at a spa resort in Arcen, The Netherlands. The control group stayed at home and continued their usual activities and drug treatment, and followed weekly group physical therapy during the 3 intervention weeks. Spaexercise therapy was standardized and consisted of group physical exercises, walking, postural correction therapy (lying supine on bed), hydrotherapy, sports, and thermal treatment by visits to either the so-called Heilstollen (Austria) or the sauna (The Netherlands). After the intervention period, all patients from the 3 groups continued weekly group physical therapy for another 37 weeks, consisting of 1 hour of physical exercises, 1 hour of sports, and 1 hour of hydrotherapy. During the intervention and the followup period, all patients continued their usual drug treatment, but were allowed to change this, if needed.

Spa-exercise therapy took place from $\mathrm{T}_{\mathrm{Ow}}$ (start of spa therapy) to $\mathrm{T}_{3 \mathrm{w}}$ (3 weeks after start of spa therapy). Assessments, consisting of questionnaires, were performed at baseline ( 2 weeks prior to spa therapy), and at 4 weeks, 16 weeks, 28 weeks, and 40 weeks after the start of spaexercise therapy.

Assessments, consisting of questionnaires were performed at baseline ( 2 weeks before spa therapy; $\mathrm{T}_{-2 \mathrm{w}}$ ), and at 4 weeks $\left(\mathrm{T}_{4 \mathrm{w}}\right), 16$ weeks $\left(\mathrm{T}_{16 \mathrm{w}}\right), 28$ weeks $\left(\mathrm{T}_{28 \mathrm{w}}\right)$, and 40 weeks $\left(\mathrm{T}_{40 \mathrm{w}}\right)$ after the start of spa-exercise therapy.

Effectiveness measurement. The primary outcomes of the study were functional ability assessed by the Bath Ankylosing Spondylitis Functional Index (BASFI) (3), pain assessed by a $10-\mathrm{cm}$ visual analog scale (VAS), global well-being assessed by a 10-cm VAS, and duration of morning stiffness in minutes. The BASFI contains 10 questions concerning activities of daily living, scored on a 10-cm VAS with anchors "easy" and "impossible" at either end. The mean of the items defines the final score, ranging from 0 (best) to 10 (worst). The BASFI has been shown to be a valid, reliable, and responsive instrument for measuring function in AS (3-7). The results on the BASFI are used here to express effectiveness of the intervention and to calculate the cost-effectiveness ratio. The scores on the pain and global question range from 0 (best) to 10 (worst).

Utility measurement. Utilities refer to preferences individuals or society may have for any particular health state (8). For the present study, the EuroQol (EQ-5D $\mathrm{D}_{\text {utility }}$ ) was chosen to assess utility from a societal perspective (9). The EQ-5 $\mathrm{D}_{\text {utility }}$ measures quality of life in 5 dimensions: mobility, self care, usual activities, pain/discomfort, and anxiety/depression. Each dimension can be divided into 3 levels of severity: "no problems," "some problems," and "severe problems." The levels for each dimension are combined into one health state. For each of the possible health states, a utility is attributed from a societal point of view, based on a large population survey using the time-trade-off procedure $(10,11)$. The final utility score ranges from 0 (representing death) to 1 (full health). The results of a cost-utility analysis are expressed as quality-adjusted life years (QALYs). A QALY is a composite index that includes effects in terms of both quality of life (utility) and the duration of time in such a health state (8).

Costs. In this incremental cost-effectiveness and costutility analysis, the recommendations proposed by the Dutch Guidelines for Pharmaco-Economic Analyses were followed as closely as possible (12). Direct (health care and non-health care) as well as indirect (non-health care) costs were included. Only costs related to AS were considered, including predefined AS-related disorders such as uveitis, inflammatory bowel disease, and psoriasis. The time horizon to measure costs was limited to the duration of the study (40 weeks).

Direct and indirect costs. All direct and indirect costs included are presented in Table 1. Acquisition of aids and appliances or adaptations to house or car were excluded, because they were considered not to be influenced by the intervention. For transport costs, only transport to and from the spa resort was considered (incorporated in the overall costs for spa-exercise therapy). Costs of informal (unpaid) help and patients' reported loss of time due to AS were not included in the base-case analysis. We assumed that the time spent on informal help was done in leisure time, i.e., not creating productivity loss of the helping person. Similarly, inactivity was also considered as taking place in leisure time, otherwise, this would have been registered as days of illness-related absence from work.

Resources. All resource utilization and number of days of illness-related absence from work were measured during the entire study period in a cost diary adapted from Goossens et al (13). Data from the day the intervention groups left for spa-exercise therapy up to 40 weeks afterwards were used for analysis. Patients made the determination as to whether the costs were related to AS or not. 


\begin{tabular}{|c|c|c|c|}
\hline Category costs & Method of valuation & Source of costs & Euro per unit \\
\hline \multicolumn{4}{|l|}{ Direct health care } \\
\hline Spa therapy in Bad Hofgastein, Austria & Market price & $\begin{array}{l}\text { Spa resort Bad } \\
\text { Hofgastein, Austria }\end{array}$ & 1739 \\
\hline Spa therapy in Arcen, Netherlands & Market price & $\begin{array}{l}\text { Spa resort Arcen, The } \\
\text { Netherlands }\end{array}$ & 1515 \\
\hline Weekly group physical therapy & Market price & $\begin{array}{l}\text { Ankylosing spondylitis } \\
\text { patient society }\end{array}$ & 306 \\
\hline Visit to general practitioner & $\begin{array}{l}\text { Cost per visit based on true cost } \\
\text { calculations }\end{array}$ & DGEE & 16.59 \\
\hline $\begin{array}{l}\text { Outpatient visit to specialist in } \\
\text { university hospital }\end{array}$ & $\begin{array}{l}\text { Cost per visit based on true cost } \\
\text { calculations }\end{array}$ & DGEE & 40.84 \\
\hline $\begin{array}{l}\text { Outpatient visit to specialist in non- } \\
\text { university hospital }\end{array}$ & $\begin{array}{l}\text { Cost per visit based on true cost } \\
\text { calculations }\end{array}$ & DGEE & 72.60 \\
\hline Alternative health care & $\begin{array}{l}\text { Price per session or medication } \\
\text { as registered by patient }\end{array}$ & Cost diary & \\
\hline Physiotherapy & $\begin{array}{l}\text { Cost per session based on true } \\
\text { cost calculations }\end{array}$ & DGEE & 18.15 \\
\hline Medication & $\begin{array}{l}\text { Reimbursable price per } \\
\text { prescription augmented with } \\
\text { an extra contribution }(€ 5.26) \text { or } \\
\text { price paid by patient in case of } \\
\text { OTC medication }\end{array}$ & TAXE & \\
\hline Additional diagnostic tests & Tariff & COTG & \\
\hline Admission to university hospital & $\begin{array}{l}\text { Day-price based on true cost } \\
\text { calculations }\end{array}$ & DGEE & 331.72 \\
\hline Admission to non-university hospital & $\begin{array}{l}\text { Day-price based on true cost } \\
\text { calculations }\end{array}$ & DGEE & 235.97 \\
\hline Visit to emergency department & Integral (true) costs & $\begin{array}{l}\text { Financial department } \\
\text { hospital in question }\end{array}$ & 199.66 \\
\hline Day care in rehabilitation center & $\begin{array}{l}\text { Cost per hour based on true cost } \\
\text { calculations }\end{array}$ & DGEE & 79.87 \\
\hline \multicolumn{4}{|l|}{ Direct non-health care } \\
\hline Formal help in household & $\begin{array}{l}\text { Cost per hour as stated by patient } \\
\text { or based on true cost } \\
\text { calculations }\end{array}$ & Cost diary or DGEE & As stated or 8.53 \\
\hline Personal allowance & Integral (true) costs & Cost diary & \\
\hline \multicolumn{4}{|l|}{ Indirect non-health care } \\
\hline Workday lost because of illness & $\begin{array}{l}\text { Production value of working day } \\
\text { based on gross earnings of } \\
\text { patient }\end{array}$ & Cost diary & \\
\hline
\end{tabular}

Valuation of costs. For the valuation of the health care costs, opportunity costs (representing market prices) are preferred from a theoretical point of view (12). In this comparative study they are reflected best by integral (i.e., true) costs. In The Netherlands, integral costs are not available for all resources (14). In these cases, tariffs were used (prices negotiated by health insurance companies). In Table 1, the method of valuation and source of all cost categories are presented and, if applicable, costs specified. The market price was used for the total cost of the spa-exercise therapy (see Table 2) and weekly group physical therapy (consisting of the honorarium of the physiotherapists, rent of sports and swimming accommodation, materials, and administrative costs). For the costs due to loss of productivity attributable to AS or related disorders, the friction cost method was used $(15,16)$. In this method, the period of production loss due to illness is limited to the time needed to replace a sick worker or to reorganize the production process ( 4 months). The production value of this friction period was based on the reported gross earnings of the patients, corrected for part-time work and, if applicable, for the percentage of disability benefits.

All costs were calculated in Euros $(€)$. Costs for 1999 were used and if not available for 1999, they were adapted using the Dutch health-specific price index (14).

Statistical analysis. The clinical trial was designed as an intent-to-treat analysis and the sample size was based on clinical outcomes (2). Between-group differences in clinical outcomes and utilities were analyzed by Student's $t$-tests for unpaired observations. Not normally distributed data were analyzed by Mann-Whitney U test. A timeintegrated summary score, the area under the curve (AUC), 


\begin{tabular}{|c|c|c|}
\hline & $\begin{array}{c}\text { Group } 1 \\
\text { Spa therapy } \\
\text { Austria }\end{array}$ & $\begin{array}{c}\text { Group 2 } \\
\text { Spa therapy } \\
\text { The Netherlands }\end{array}$ \\
\hline $\begin{array}{l}\text { Travel costs from home } \\
\text { to spa resort }\end{array}$ & 102 & 11 \\
\hline $\begin{array}{l}\text { Hotel accommodation } \\
\text { (all meals included) } \\
\text { and attendant }\end{array}$ & 842 & 1040 \\
\hline $\begin{array}{c}\text { Travel costs from hotel } \\
\text { to spa resort during } \\
\text { treatment period }\end{array}$ & 29 & 89 \\
\hline $\begin{array}{l}\text { Therapy costs and } \\
\text { medical treatment }\end{array}$ & 766 & 375 \\
\hline Total costs & 1739 & 1515 \\
\hline
\end{tabular}

defined the effects and utilities over time. The AUC of the change from baseline was calculated with the trapezium rule standardized by the study duration $(17,18)$.

Resource utilization and costs are reported as arithmetic means $( \pm S D$ ) per patient per group (19). The differences in volumes of resource utilization were analyzed by MannWhitney U test. The 95\% confidence interval (95\% CI) around the mean total costs per patient and the betweengroup differences in mean total costs were estimated with bootstrapping, repeating the analysis 10,000 times (20).

The incremental cost-effectiveness ratio was calculated by dividing the extra costs for the intervention group by the extra effects derived from it. The incremental costutility ratio was calculated by dividing the extra costs for the intervention group by the extra utilities derived from it, and expressed as costs per QALY gained. The 95\% CIs of the ratios were estimated with bootstrapping. Because the time horizon of this study was $<1$ year, neither costs nor effects were discounted.

Sensitivity analysis. Four one-way sensitivity analyses were performed: 1) Costs of informal (unpaid) help were added to the base-case analysis. The costs per hour were based on a shadow price of €7.94. 2) Costs of patientreported inactivity were added to the base-case analysis. In the cost diary, only the number of days lost due to inactivity was registered. Therefore, 2 analyses were performed considering a day of inactivity being either 4 or 8 hours. The costs per hour were based on a shadow price of $€ 7.94 .3)$ The number of days of sick leave during spaexercise therapy was varied. Only a few patients from the intervention groups reported sick leave during the 3 intervention weeks; most patients had voluntarily taken days off from work. The mean total costs and costs per QALY were recalculated first assuming that all patients would be on sick leave during the 3 intervention weeks, and second assuming that all patients would need to voluntarily take days off from work. 4) The outcome measures "global well-being" and "pain" were used as measures of effectiveness of the intervention in the incremental cost-effectiveness ratio. Morning stiffness was not investigated in a sensitivity analysis because it has a different scale (0 to infinite) compared with the other outcome measures (0 to 10), which could be misleading in cost-effectiveness ratios. In addition, morning stiffness is not sensitive to change.

\section{RESULTS}

Of the 120 participating patients, 9 did not complete the cost diary (2 from group 1, 4 from group 2, 3 from the

\begin{tabular}{|c|c|c|c|}
\hline & $\begin{array}{c}\text { Group } 1 \\
\text { Spa therapy } \\
\text { Austria } \\
(\mathbf{n}=\mathbf{3 8})\end{array}$ & $\begin{array}{c}\text { Group } 2 \\
\text { Spa therapy } \\
\text { The Netherlands } \\
(\mathbf{n}=\mathbf{3 6})\end{array}$ & $\begin{array}{c}\text { Control group } \\
\text { physical therapy, } \\
\text { home } \\
(\mathbf{n}=37)\end{array}$ \\
\hline Male/female & $24 / 14$ & $24 / 12$ & $31 / 6$ \\
\hline Aget (years) & $\begin{array}{c}47(10) \\
\text { (range 29-68) }\end{array}$ & $\begin{array}{l}48(9) \\
\text { (range 25-66) }\end{array}$ & $\begin{array}{c}48(10) \\
\text { (range 29-63) }\end{array}$ \\
\hline Disease durationt (years) & $11(6)$ & $12(5)$ & $10(6)$ \\
\hline Inflammatory bowel disease (yes/no) & $7 / 31$ & $5 / 31$ & $9 / 28$ \\
\hline Uveitis (yes/no) & $10 / 28$ & $15 / 21$ & $18 / 19$ \\
\hline Psoriasis (yes/no) & $4 / 34$ & $4 / 32$ & $4 / 33$ \\
\hline Educationt (years) & $12(4)$ & $12(4)$ & $13(4)$ \\
\hline Manual/nonmanual profession & $15 / 20$ & $6 / 27$ & $16 / 20$ \\
\hline Paid work (yes/no) & $21 / 17$ & $17 / 19$ & $23 / 14$ \\
\hline \multicolumn{4}{|l|}{ Reasons no work $\neq$} \\
\hline Household & 3 & 3 & 1 \\
\hline (Early) retirement & 2 & 4 & 2 \\
\hline Work disability & 13 & 12 & 12 \\
\hline Unemployment & 0 & 1 & 0 \\
\hline Own choice & 0 & 4 & 0 \\
\hline
\end{tabular}




\begin{tabular}{|c|c|c|c|c|c|c|}
\hline \multirow[b]{2}{*}{ Measure (range) } & \multirow{2}{*}{$\begin{array}{c}\text { Baseline } \\
\text { value } T_{-2 w}\end{array}$} & \multicolumn{4}{|c|}{ Change from baseline } & \multirow{2}{*}{$\begin{array}{c}\text { Mean AUC of } \\
\text { change during } \\
\text { study period }\end{array}$} \\
\hline & & $\mathbf{T}_{4 \mathrm{w}}$ & $\mathrm{T}_{16 \mathrm{w}}$ & $\mathbf{T}_{28 \mathrm{w}}$ & $\mathrm{T}_{40 \mathrm{w}}$ & \\
\hline \multicolumn{7}{|l|}{ BASFI (0-10) } \\
\hline Group 1 & $4.9(1.8)$ & $1.1(1.5) \ddagger$ & $1.0(1.6)+$ & $0.7(1.5) \dagger$ & $0.4(1.3)$ & $1.0(1.3) \neq$ \\
\hline Group 2 & $4.2(2.0)$ & $0.8(1.2) \ddagger$ & $0.5(1.1)$ & $0.0(1.2)$ & $0.0(1.1)$ & $0.6(1.0) \dagger$ \\
\hline Controls & $4.2(2.1)$ & $0.0(1.1)$ & $0.0(1.7)$ & $-0.1(1.7)$ & $-0.1(1.3)$ & $0.0(1.1)$ \\
\hline \multicolumn{7}{|c|}{ Global wellbeing (0-10) } \\
\hline Group 1 & $5.2(2.0)$ & $1.3(2.8)$ & $2.3(2.4)+$ & $1.4(2.6)$ & $1.1(2.6)$ & $1.5(2.1) \dagger$ \\
\hline Group 2 & $5.3(2.4)$ & $1.8(2.6) \dagger$ & $1.3(3.0)$ & $1.0(2.9)$ & $0.4(2.6)$ & $1.5(2.5)$ \\
\hline Controls & $4.8(2.4)$ & $0.3(3.0)$ & $0.6(3.1)$ & $0.4(2.8)$ & $0.4(2.8)$ & $0.4(2.6)$ \\
\hline \multicolumn{7}{|l|}{ Pain (0-10) } \\
\hline Group 1 & $4.6(2.5)$ & $0.7(2.4)$ & $1.4(2.7)$ & $0.8(2.8)$ & $0.1(2.4)$ & $1.0(2.0)+$ \\
\hline Group 2 & $4.6(2.5)$ & $1.4(2.6)+$ & $1.1(2.7)$ & $-0.3(3.0)$ & $-0.4(2.8)$ & $1.1(2.3)$ \\
\hline Controls & $4.6(2.7)$ & $0.1(2.3)$ & $0.4(2.8)$ & $0.0(2.8)$ & $-0.2(2.1)$ & $0.1(2.1)$ \\
\hline \multicolumn{7}{|c|}{ Morning stiffness (min)§ } \\
\hline Group 1 & $30(10 ; 60)$ & $3(0 ; 21)$ & $3(0 ; 17)$ & $0(-6 ; 15)$ & $0(-9 ; 11)$ & $8.9(21.0)$ \\
\hline Group 2 & $30(15 ; 60)$ & $0(0 ; 18)$ & $0(-5 ; 15)$ & $0(-6 ; 14)$ & $0(-15 ; 12)$ & $3.1(24.5)$ \\
\hline Controls & $30(10 ; 56)$ & $5(0 ; 10)$ & $4(-5 ; 15)$ & $0(-13 ; 10)$ & $0(-5 ; 15)$ & $-3.4(30.4)$ \\
\hline \multicolumn{7}{|l|}{ EQ-5D utility $(0-1)$} \\
\hline Group 1 & $0.64(0.22)$ & $0.10(0.24) \ddagger$ & $0.12(0.24) \ddagger$ & $0.10(0.21) \ddagger$ & $0.03(0.23)$ & $0.11(0.20) \neq$ \\
\hline Group 2 & $0.65(0.22)$ & $0.02(0.20)+$ & $0.04(0.21)+$ & $-0.03(0.23)$ & $-0.01(0.27)$ & $0.02(0.17) \dagger$ \\
\hline Controls & $0.72(0.10)$ & $-0.06(0.18)$ & $-0.04(0.19)$ & $-0.08(0.28)$ & $-0.03(0.19)$ & $-0.06(0.14)$ \\
\hline $\begin{array}{l}{ }^{*} \text { Data are presented as } \mathrm{m} \\
\text { spa therapy, The Netherl } \\
\dagger P<0.05 \text {. } \\
\neq P<0.01 \text { between inter } \\
\text { § Skewed data are presen }\end{array}$ & $\begin{array}{l}\text { ) at baselin } \\
\text { ontrols ( }= \\
\text { group and } \\
\text { median (inte }\end{array}$ & $\begin{array}{l}\text { as mean char } \\
\text { ome. Positive } \\
\text { l group. } \\
\text { ile range) an }\end{array}$ & $\begin{array}{l}\mathrm{SD}_{\text {change }} \text { ) from } \\
\text { inges imply im } \\
\text { edian change ( }\end{array}$ & $\begin{array}{l}\text { ne. Group } 1 \text { ( } \\
\text { nent. }\end{array}$ & a therapy, A & group $2(n=36)$ \\
\hline
\end{tabular}

control group), but they did not differ from the patient groups with respect to sex, age, work, or education. All analyses are based on the 111 (93\%) patients who completed the cost diary. The baseline characteristics of the groups are presented in Table 3 . All characteristics, except sex, were well balanced among the groups. Relatively fewer women were randomly allocated to the control group compared with both intervention groups.

Clinical outcomes and utilities. The clinical outcomes and utilities of the 111 patients are listed in Table 4.
Improvements in all primary outcomes, except for morning stiffness, were found in both intervention groups after spa-exercise therapy. The between-group differences in the AUC for the BASFI of 1.0 (95\% CI 0.4-1.6) for group 1 versus controls and of 0.6 (95\% CI $0.1-1.1)$ for group 2 versus controls were both statistically significant $(P=$ 0.001, $P=0.020$, respectively). After adjustment for the score of the control group, the mean improvement over the entire study period in BASFI was $20 \%$ compared with baseline for group 1, and 14\% for group 2 .

The between-group difference in the AUC of the EQ-

\begin{tabular}{|c|c|c|c|}
\hline & $\begin{array}{c}\text { Group } 1 \\
\text { Spa therapy } \\
\text { Austria } \\
(\mathbf{n}=\mathbf{3 8})\end{array}$ & $\begin{array}{c}\text { Group 2 } \\
\text { Spa therapy } \\
\text { The Netherlands } \\
(\mathrm{n}=\mathbf{3 6})\end{array}$ & $\begin{array}{c}\text { Control group } \\
\text { home } \\
(n=37)\end{array}$ \\
\hline Visits to general practitioner & $1.6(2.5)$ & $1.3(2.0)$ & $1.7(2.1)$ \\
\hline Visits to specialists (outpatient) & $2.0(2.0)$ & $1.9(2.3)$ & $2.5(2.9)$ \\
\hline Physiotherapy sessions & $17.0(20.9)$ & $14.9(21.9)$ & $21.5(24.3)$ \\
\hline Prescribed and OTC medication & $4.3(6.0) \ddagger$ & $4.5(4.8) \dagger$ & $6.1(4.5)$ \\
\hline Prescribed and OTC alternative medication & $0.5(1.8)$ & $0.2(0.7)$ & $0.1(0.7)$ \\
\hline Visits to alternative practitioner & $0.4(1.7)$ & $0.3(1.2)$ & $0.8(2.7)$ \\
\hline Formal help in household (hours) & $17.3(45.0)$ & $12.7(31.7)$ & $11.5(34.8)$ \\
\hline
\end{tabular}




\begin{tabular}{|c|c|c|c|}
\hline & $\begin{array}{c}\text { Group } 1 \\
\text { Spa therapy } \\
\text { Austria } \\
(\mathbf{n}=\mathbf{3 8})\end{array}$ & $\begin{array}{c}\text { Group 2 } \\
\text { Spa therapy } \\
\text { The Netherlands } \\
(\mathbf{n}=\mathbf{3 6})\end{array}$ & $\begin{array}{c}\text { Control group } \\
\text { home } \\
(n=37)\end{array}$ \\
\hline \multicolumn{4}{|l|}{ Direct costs } \\
\hline \multicolumn{4}{|l|}{ Health care costs } \\
\hline Spa therapy & $1739(0)$ & $1515(0)$ & - \\
\hline Group physical therapy & $306(0)$ & $306(0)$ & $306(0)$ \\
\hline $\begin{array}{l}\text { Health care professionals } \\
\text { (GP and specialist) }\end{array}$ & $112(109)$ & $107(142)$ & $163(168)$ \\
\hline Physiotherapy & $308(379)$ & $271(398)$ & $391(440)$ \\
\hline Medications (prescription and OTC) & $153(239)$ & $182(234)$ & $206(177)$ \\
\hline Additional diagnostic tests & $38(72)$ & $24(80)$ & $23(39)$ \\
\hline $\begin{array}{l}\text { Hospitalization and day care } \\
\text { rehabilitation }\end{array}$ & $24(174)$ & $26(157)$ & $86(525)$ \\
\hline Alternative health care & $24(89)$ & $3(12)$ & 35 (106) \\
\hline $\begin{array}{l}\text { Sum direct health care costs } \\
\text { (excluding spa therapy) }\end{array}$ & $964(744)$ & $919(625)$ & $1210(785)$ \\
\hline $\begin{array}{l}\text { Sum direct health care costs } \\
\text { (including spa therapy) }\end{array}$ & $2703(744)$ & $2434(625)$ & $1210(785)$ \\
\hline \multicolumn{4}{|l|}{ Non-health care costs } \\
\hline Formal help in household & $106(275)$ & $100(256)$ & $72(220)$ \\
\hline Personal allowance & $2(10)$ & $14(83)$ & $11(67)$ \\
\hline \multicolumn{4}{|l|}{ Indirect costs } \\
\hline Absenteeism from work & $211(549)$ & $693(2864)$ & $461(1204)$ \\
\hline $\begin{array}{l}\text { Sum direct and indirect costs } \\
\text { (excluding spa therapy) }\end{array}$ & $1284(1009)$ & 1725 (2988) & $1754(1772)$ \\
\hline $\begin{array}{l}\text { Sum direct and indirect costs } \\
\text { (including spa therapy) }\end{array}$ & 3023 (1009) & $3240(2988)$ & $1754(1772)$ \\
\hline
\end{tabular}

$5 \mathrm{D}_{\text {utility }}$ was 0.17 (95\% CI $\left.0.09-0.25, P<0.001\right)$ for group 1 versus controls, and 0.08 (95\% CI $0.00-0.15, P=0.04$ ) for group 2 versus controls.

Health resource utilization and costs. The volumes of health care and non-health care utilization during the followup period are listed in Table 5 . The number of prescribed and over-the-counter medications was significantly lower in both intervention groups compared with controls $(P=0.006$ group 1 versus controls; $P=0.032$ group 2 versus controls). The number of hours and costs of formal help in household were higher in both intervention groups compared with the control group, but the differences were not statistically significant.

Of the patients with a paid job, 7 from group 1 (33\%), 4 from group $2(24 \%)$, and 9 from the control group (39\%) reported AS-related absence from work during the study period, including 3 patients from group 1 and 4 patients from group 2 who reported sick leave during the spa therapy period. The mean number of days $( \pm S D)$ of illness due to AS was $2.5( \pm 6.5)$ for group $1,6.4( \pm 26.4)$ for group 2, and $6.1( \pm 15.8)$ for the control group.

Direct and indirect costs per patient for each category are listed in Table 6. Mean total costs were $€ 3,023$ (95\% CI $2,728-3,359)$ for group $1, € 3,240$ (95\% CI 2,553-4,391) for group 2, and $€ 1,754$ (95\% CI 1,268-2,402) for the control group. The mean total incremental costs were $€ 1,269$ (95\% CI 565-1,867) for group 1 and $€ 1,486$ (95\% CI 501-2,707) for group 2 .
Cost effectiveness and cost utility. The incremental cost-effectiveness ratio per unit effect gained in function ability on a 0-10 scale (based on the AUC of the BASFI) was $€ 1,269 / 1.0=€ 1,269$ (95\% CI 497-3,316) for group 1, and $€ 1,486 / 0.6=€ 2,477$ (95\% CI 601-12,098) for group 2 .

Assuming that the difference in AUC of the EQ-5D utility will be equal to 0 during the last 3 months of the year after a 3-week course of spa-exercise therapy, and that the costs will be equal in all 3 groups (because no extended effect of the intervention is expected, the cost will presumably equal the costs of the control group), the cost per QALY gained would be $€ 1,269 / 0.17=€ 7,465$ (95\% CI 3,29414,686) for group 1 , and $€ 1,486 / 0.08=€ 18,575$ (95\% CI $3,678-114,257)$ for group 2.

Sensitivity analysis. In Table 7 the mean total costs per patient per group and the mean costs per QALY gained are shown for each of the additional costs or alternatives calculated in the sensitivity analysis.

Informal help. The mean $( \pm \mathrm{SD})$ number of hours of informal help was $22.9( \pm 67.7)$ in group $1,25.4( \pm 76.4)$ in group 2, and $19.9( \pm 76.6)$ in the control group. Additional costs for informal help would be $€ 182$ ( \pm 537 ) for group 1 , $€ 202( \pm 607)$ for group 2 , and $€ 158( \pm 608)$ for the control group. The costs per QALY gained would slightly increase (Table 7.)

Inactivity. The mean ( \pm SD) number of days of inactivity was $7.3( \pm 19.1)$ in group $1,4.6( \pm 12.5)$ in group 2 , and 7.8 $( \pm 21.3)$ in the control group. Applying 4 hours per day as 


\begin{tabular}{|c|c|c|c|c|c|c|c|}
\hline & \multicolumn{3}{|c|}{ Mean total costs } & \multicolumn{2}{|c|}{$\begin{array}{l}\text { Incremental costs } \\
\text { per QALY gained }\end{array}$} & \multicolumn{2}{|c|}{$\begin{array}{l}\text { Incremental costs per } \\
\text { unit of effect gained } \\
\text { on a 0-10 scale }\end{array}$} \\
\hline & Group 1 & Group 2 & Controls & Group 1 & Group 2 & Group 1 & Group 2 \\
\hline Base-case analysis (with BASFI) & 3,023 & 3,240 & 1,754 & 7,465 & 18,575 & 1,269 & 2,477 \\
\hline \multicolumn{8}{|l|}{ Sensitivity analysis } \\
\hline Informal help in household & 3,205 & 3,442 & 1,912 & 7,606 & 19,125 & 1,293 & 2,550 \\
\hline Inactivity 4 hours/day & 3,256 & 3,386 & 2,003 & 7,371 & 17,288 & 1,253 & 2,305 \\
\hline Inactivity 8 hours/day & 3,488 & 3,533 & 2,252 & 7,271 & 16,013 & 1,236 & 2,135 \\
\hline Absenteeism work during spa therapy & 3,523 & 3,690 & 1,754 & 10,406 & 24,200 & 1,769 & 3,227 \\
\hline Voluntary days off during spa therapy & 2,965 & 3,047 & 1,754 & 7,124 & 16,163 & 1,211 & 2,155 \\
\hline $\begin{array}{l}\text { CEA with global well-being as outcome } \\
\text { measure }\end{array}$ & 3,023 & 3,240 & 1,754 & 7,465 & 18,575 & 1,154 & 1,351 \\
\hline CEA with pain as outcome measure & 3,023 & 3,240 & 1,754 & 7,465 & 18,575 & 1,410 & 1,486 \\
\hline
\end{tabular}

the mean number of hours of inactivity, the additional costs would be $€ 233$ ( \pm 606 ) for group 1, €146 ( \pm 398 ) for group 2, and $€ 249$ ( \pm 678 ) for the control group. In case a day of inactivity would represent 8 hours, the additional costs would be $€ 465$ ( $\pm 1,212$ ) for group 1 , €293 ( \pm 795 ) for group 2 , and $€ 498( \pm 1,356)$ for the control group. Due to higher reported inactivity in the control group, the costs per QALY gained would decrease for both intervention groups (Table 7).

Absenteeism from work. If all patients who work were on sick leave during spa therapy, the mean ( \pm SD) number of days of illness would be $7.5( \pm 9.2)$ in group 1 , and 10.9 $( \pm 26.3)$ in group 2 , both significantly more than the control group $(P=0.020$ group 1 versus controls, $P=0.032$ group 2 versus controls). The costs per QALY gained would increase to $€ 10,406$ for group 1 , and $€ 24,200$ for group 2. If all patients voluntarily took days off to follow spa therapy, the mean number of days of illness would decrease to $1.9( \pm 5.7)$ for group 1 and 4.7 ( \pm 23.8$)$ for group 2 . The costs per QALY gained would decrease to $€ 7,124$ for group 1, and €16,163 for group 2 .

Cost effectiveness. When "global well-being" and "pain" are used as outcome measures in the cost-effectiveness study, the incremental costs per unit of effect gained are more or less similar for both intervention groups. Compared with the base-case analysis, group 2 showed considerably fewer incremental costs per unit of effect gained (Table 7).

\section{DISCUSSION}

This economic evaluation shows that a 3-week course of spa-exercise therapy in addition to standard treatment has favorable cost-effectiveness and cost-utility ratios compared with standard treatment alone in patients with AS. Cost savings were found for both intervention groups compared with the control group with respect to visits to health care professionals, physiotherapy, and use of medication. In the sensitivity analyses, the results were robust to variation in several cost categories, but were sensitive to variation in indirect costs. The incremental cost ratios would considerably increase for both intervention groups if all patients with a paid job were on sick leave during spa-exercise therapy instead of considering the treatment period as regular holidays.

Only one cost analysis of spa therapy could be found in the English literature (21). The study evaluated the cost effectiveness of (undefined) spa therapy for a variety of rheumatic diseases, measured from a health insurance company's perspective. Effectiveness was assessed indirectly through determination of health care utilization before and after the intervention, based on reimbursement claims. No decrease in health care utilization was found in the groups that received spa therapy compared with controls. However, some concerns have been raised about the methodology of the study with respect to patient recruitment, lack of baseline description of the groups, the randomization procedure, and inadequate statistical procedures (22). Therefore, no reasonable comparison with the present study can be made.

Expressing the effects of an intervention in terms of “cost per QALY gained” has become increasingly popular in recent years. The primary argument was to facilitate the allocation of health care resources by decision makers, because the QALY concept allows comparison among different interventions in different diseases (23). Incremental cost-utility ratios can be listed in league tables, in which the costs per QALY gained for each study are visible at a glance. There are, however, a number of disadvantages in using league tables (24). League tables suggest homogeneity in, and comparability among, study designs. However, studies included in league tables might have been conducted in different years with consequently different technologies and relative prices. The approaches to measuring utilities differ greatly among studies; some studies include only direct costs, whereas others also report indirect costs, and not all studies apply discounting, if necessary. In addition, the amount of costs per QALY gained is dependent on the alternative program. An intervention will show fewer costs per QALY gained if compared with "do- 
ing nothing" instead of with the "best alternative treatment."

The incremental costs per QALY gained for each of the intervention groups (€7,465 for group 1; €18,575 for group 2) are relatively high compared with the rather low prevalent costs for patients with AS $(€ 1,754)$. This probably reflects the absence of effective (curative) treatment for AS. Drug treatment is mostly limited to NSAIDs. Also, the costs for weekly group physical therapy are relatively low (25). These low prevalent costs contrast with the important impact the disease has with respect to pain, well-being, and work ability $(26,27)$. The latest developments in the treatment of AS include the administration of tumor necrosis factor $\alpha$ (TNF $\alpha$ ) inhibiting drugs, which have been reported to yield dramatic improvements $(28,29)$. Due to the huge costs of anti-TNF $\alpha$ treatment (approximately $€ 11,000$ per patient per year) it is not to be expected that cost-utility analyses with respect to these new drugs will reveal costs per QALY gained that are lower than demonstrated by us. It is probable that these studies might show even larger discrepancies between the costs per QALY gained for the intervention groups, compared with the prevalent costs of the control group.

A few methodologic issues should be considered. First, the data as reported by the patients in the diaries were not ascertained by consulting other data sources. It is conceivable that patients might have had different opinions as to what is related to AS. Second, there were no data available on non-health care expenditures and days of illness-related absence from work during the pretrial period. Therefore, no comparison with the previous year can be made, and preexisting differences in non-health care utilization between the groups cannot be excluded. Third, the generalizability of the study findings is restricted to Dutch patients with active AS who follow weekly group physical therapy and have a disease duration of $<20$ years. The results might differ when other spa resorts are visited or different programs are provided. Similarly, the costs are likely to be different for other countries with other health care systems.

In The Netherlands, reimbursement for spa therapy is provided by a few insurance companies for a limited number of diseases (usually rheumatoid arthritis and AS only), with a maximum reimbursement level. It is estimated that $0.1 \%$ of the Dutch population has AS ( 16,000 patients) (30). Approximately $20 \%$ of them follow weekly group physical therapy. If reimbursement for spa therapy would be limited to these 3,200 patients, who have adhered to treatment by following weekly group physical therapy, then the incremental societal costs for providing spa therapy would be $€ 4,408,000$ annually. In exchange for these costs, a large, although temporary, improvement in functional outcome and quality of life will be gained in a group of patients for whom no curative treatment is yet available.

In conclusion, a 3-week course of combined spa-exercise therapy in addition to standard treatment with NSAIDs and weekly group physical therapy provides beneficial effects compared with standard treatment alone, and can be regarded as cost effective in patients with AS.

\section{ACKNOWLEDGMENTS}

We thank the participating patients, D. Martens and B. van Albada from the Dutch league of associations of patients with rheumatic disorders, J. Daanen from Thermaalbad Arcen, M. Schafflinger from Kurzentrum Thermentempel Bad Hofgastein, F. Hartlieb and A. Falkenbach from the Gasteiner Heilstollen, M. Asscher, N. Wolter, E. Genth, H. Goei Thè, J. Thomassen, and all others who have contributed to the successful completion of this study.

\section{REFERENCES}

1. Van Tubergen A, Landewe $R$, van der Linden $S$. Spondylarthropathies: options for combination therapy. Springer Semin Immunopathol 2001;23:147-63.

2. Van Tubergen A, Landewe R, van der Heijde D, Hidding A, Wolter N, Asscher M, et al. Combined spa-exercise therapy is effective in patients with ankylosing spondylitis: a randomized controlled trial. Arthritis Rheum (Arthritis Care Res) 2001;45:430-8

3. Calin A, Garrett S, Whitelock H, Kennedy LG, O’Hea J, Mallorie $\mathrm{P}$, et al. A new approach to defining functional ability in ankylosing spondylitis: the development of the Bath Ankylosing Spondylitis Functional Index. J Rheumatol 1994;21: 2281-5.

4. Calin A, Nakache JP, Gueguen A, Zeidler H, Mielants H, Dougados M. Outcome variables in ankylosing spondylitis: evaluation of their relevance and discriminant capacity. J Rheumatol 1999;26:975-9.

5. Ruof J, Stucki G. Comparison of the Dougados Functional Index and the Bath Ankylosing Spondylitis Functional Index: a literature review. J Rheumatol 1999;26:955-60.

6. Ruof J, Sangha O, Stucki G. Comparative responsiveness of 3 functional indices in ankylosing spondylitis. J Rheumatol 1999;26:1959-63.

7. Spoorenberg A, van der Heijde D, de Klerk E, Dougados M, de Vlam K, Mielants H, et al. A comparative study of the usefulness of the Bath Ankylosing Spondylitis Functional Index and the Dougados Functional Index in the assessment of ankylosing spondylitis. J Rheumatol 1999;26:961-5.

8. Drummond M. Methods for the economic evaluation of health care programs. 2nd ed. Oxford: Oxford Medical Publications; 1997.

9. The EuroQoL Group. EuroQoL: a new facility for the measurement of health-related quality of life. Health Policy 1990;16: 199-208.

10. Dolan P, Gudex C, Kind P, Williams A. The time trade-off method: results from a general population study. Health Econ 1996;5:141-54.

11. Dolan P. Modeling valuations for EuroQol health states. Med Care 1997;35:1095-108.

12. Riteco JA, de Heij LJM, van Luijn JCF, Wolff I. Guidelines for pharmaco-economic research [in Dutch]. Amstelveen: College voor zorgverzekeringen; 1999.

13. Goossens ME, Rutten van Molken MP, Vlaeyen JW, van der Linden SM. The cost diary: a method to measure direct and indirect costs in cost-effectiveness research. J Clin Epidemiol 2000;53:688-95.

14. Oostenbrink JB, Koopmanschap MA, Rutten FFH. Guidelines for cost-analysis: methods and guideline prices for economic evaluations in health care [in Dutch]. Amstelveen: College voor zorgverzekeringen; 2000.

15. Koopmanschap MA, van Ineveld BM. Towards a new approach for estimating indirect costs of disease. Soc Sci Med 1992;34:1005-10.

16. Koopmanschap MA, Rutten FFH. A practical guide for calculating indirect costs of disease. PharmacoEconomics 1996;10: 460-6.

17. Matthews JN, Altman DG, Campbell MJ, Royston P. Analysis of serial measurements in medical research. BMJ 1990;300: $230-5$. 
18. Pham B, Cranney A, Boers M, Verhoeven AC, Wells G, Tugwell $P$. Validity of area-under-the-curve analysis to summarize effect in rheumatoid arthritis clinical trials. J Rheumatol 1999;26:712-6.

19. Thompson SG, Barber JA. How should cost data in pragmatic randomised trials be analysed? BMJ 2000;320:1197-200.

20. Efron B, Tibshirani RJ. An introduction to the bootstrap. New York: Chapman \& Hall; 1993.

21. Allard P, Deligne J, van Bockstael V, Duquesnoy B. Is spa therapy cost-effective in rheumatic disorders? Rev Rhum Engl Ed 1998;65:173-80.

22. Graber-Duvernay B. Letter to the editor about the article: is spa therapy cost-effective in rheumatic disorders? Rev Rhum Engl Ed 1998;65:600-2.

23. Mason J, Drummond M, Torrance G. Some guidelines on the use of cost effectiveness league tables. BMJ 1993;306:570-2.

24. Drummond M, Torrance G, Mason J. Cost-effectiveness league tables: more harm than good? Soc Sci Med 1993;37:33-40.

25. Bakker C, Hidding A, van der Linden S, van Doorslaer E. Cost effectiveness of group physical therapy compared to individualized therapy for ankylosing spondylitis: a randomized controlled trial. J Rheumatol 1994;21:264-8.

26. Zink A, Braun J, Listing J, Wollenhaupt J. Disability and handicap in rheumatoid arthritis and ankylosing spondylitis: results from the German rheumatological database: German Collaborative Arthritis Centers. J Rheumatol 2000;27:613-22.

27. Boonen A, Chorus A, Miedema H, van der Heijde D, van der Tempel H, van der Linden S. Employment, work disability, and work days lost in patients with ankylosing spondylitis: a cross sectional study of Dutch patients. Ann Rheum Dis 2001; 60:353-8.

28. Brandt J, Haibel H, Cornely D, Golder W, Gonzalez J, Reddig J, et al. Successful treatment of active ankylosing spondylitis with the anti-tumor necrosis factor $\alpha$ monoclonal antibody infliximab. Arthritis Rheum 2000;43:1346-52.

29. Van den Bosch F, Kruithof E, Baeten D, De Keyser F, Mielants $\mathrm{H}$, Veys EM. Effects of a loading dose regimen of three infusions of chimeric monoclonal antibody to tumour necrosis factor alpha (infliximab) in spondyloarthropathy: an open pilot study. Ann Rheum Dis 2000;59:428-33.

30. Van der Linden SM, Valkenburg HA, de Jongh BM, Cats A. The risk of developing ankylosing spondylitis in HLA-B27 positive individuals: a comparison of relatives of spondylitis patients with the general population. Arthritis Rheum 1984; $27: 241-9$. 